\title{
Gluten-free pasta: development of a new formulation based on rice and lupine bean flour (Lupinus Mutabilis) using a mixture-process design
}

\author{
David ALBUJA-VACA ${ }^{1}$, Christian YÉPEZ ${ }^{1}$, Maria Gabriela VERNAZA ${ }^{1 * ~(D), ~ D a n n y ~ N A V A R R E T E ~}{ }^{1}$
}

\begin{abstract}
Gluten-free pasta was developed by substituting rice flour (RF) with lupin flour (LF). The factors tested were the substitution of RF by LF $(10 \mathrm{~g} / 100 \mathrm{~g}-30 \mathrm{~g} / 100 \mathrm{~g})$, egg $(8 \mathrm{~g} / 100 \mathrm{~g}-30 \mathrm{~g} / 100 \mathrm{~g})$ and guar gum $(0.15 \mathrm{~g} / 100 \mathrm{~g}-1 \mathrm{~g} / 100 \mathrm{~g})$ using a mixture-process design. Seven response variables were measured. Luminosity, ash content, protein content, chrome, hue, weight gain and loss of solids were explained by mixture-process models $(\mathrm{p}<0.05)$. LF was a significant factor due to its high protein and mineral content. A sensory analysis was performed to quantify consumer acceptance. The best formulation was obtained with $20 \mathrm{~g} / 100 \mathrm{~g} \mathrm{LF}$, $30 \mathrm{~g} / 100 \mathrm{~g}$ egg and $0.15 \mathrm{~g} / 100 \mathrm{~g}$ guar gum. A proximate analysis was performed in order to compare it with a control sample ( $100 \%$ rice flour, $30 \%$ whole egg, $0.15 \%$ guar gum). This formulation showed an increase in ash $(37.5 \mathrm{~g} / 100 \mathrm{~g})$ and protein $(63.15 \mathrm{~g} / 100 \mathrm{~g})$, fat $(112.12 \mathrm{~g} / 100 \mathrm{~g})$ and fiber $(126.66 \mathrm{~g} / 100 \mathrm{~g})$. This study showed that partial substitution of RF by LF could be a reliable alternative for gluten-free products.
\end{abstract}

Keywords: celiac disease; gluten-free pasta; Lupinus Mutabilis; mixture-process design.

Practical Application: Development of a gluten-free pasta based on rice and lupine bean flour using a mixture-process design.

\section{Introduction}

Celiac disease can be found in countries around the globe. Research indicates that 1 in every 236 people in the hispanic population suffers from this disease (Malalgoda \& Simsek 2016), compared to 1 in every 141 people in the United States or 1\% in Europe (Rubio-Tapia et al., 2012). In 1950, Dicke found wheat intake to be the main cause of celiac disease and currently about $1 \%$ of the world population suffers from this disorder (Malalgoda \& Simsek 2016).

Celiac disease is a chronic digestive disease that leads to the malabsorption of nutrients. It is commonly caused by gluten intolerance (Malalgoda \& Simsek 2016). Gluten is a protein found in wheat, rye, oat and barley (Karlin et al., 2016). This disease has attracted the attention of different research fields that are developing products that can meet celiac people's needs. Currently, the only gluten-free diet alternative is made up of foods such as rice, corn starch and sorghum, but unfortunately, all of them have a low nutritional value and content (Giuberti et al., 2015). For this reason, functional foods are being developed in order to increase the nutritional value of gluten-free foods.

In Andean countries, there is a great diversity of functional crops, among them Lupinus mutabilis (lupine bean). Consumption is found in several countries in Latin America, Ecuador being one of the largest producers (Polowick et al., 2014). Its nutritional value is high due to the fact that proteins and oils constitute more than half of its weight. Based on a bromatological analysis, it has on average $35.5 \mathrm{~g} / 100 \mathrm{~g}$ of protein,
$16.9 \mathrm{~g} / 100 \mathrm{~g}$ of oils, $7.65 \mathrm{~g} / 100 \mathrm{~g}$ of fiber, $4.15 \mathrm{~g} / 100 \mathrm{~g}$ of ash and $35.77 \mathrm{~g} / 100 \mathrm{~g}$ of carbohydrates. When compared to soybeans, this lupine comes very close in its nutritional components (Carvajal-Larenas et al., 2014). One negative characteristic is its high alkaloid content, which can cause poisoning in humans (Carvajal-Larenas et al., 2016). Also, alkaloids make the legume bitter, presenting a disadvantage with respect to the other grains (Jacobsen \& Mujica, 2006). The bitter taste and toxic components must be removed before consumption, which is completed through chemical and biological methods. The most-used method is a continuous soaking of the legume in water (Carvajal-Larenas et al., 2016), which results in a grain suitable for human consumption.

Pasta is one of the most popular foods around the world (Sarawong et al., 2014). Pasta is a highly consumed food due to its low-fat content, low sodium and low levels of glucose in the blood (glycemic response). Traditional wheat-based pasta allows protein interaction with lipids and other components to form gluten, which is essential for cooking in water, as it avoids disintegration of the pasta. However, traditional pasta (wheat base pasta) is considered an unbalanced food due to its low amount of fat and dietary fiber and the low biological value of its protein (Granito et al., 2003).

Therefore, the main objective of this research was to develop new formulation of a gluten-free pasta base on rice and lupine bean flour (Lupinus Mutabilis) using a mixture-process design. 


\section{Methods and materials}

\subsection{Materials and preparation of gluten-free pasta}

Rice flour (Oryza Sativa), whole eggs and de-bittered lupine flour (Lupinus Mutabillis) were purchased at the local market (Quito and Ibarra, Ecuador). Guar gum was purchased from Toptrading Company (Quito-Ecuador). To obtain pasta, different formulations described in Table 1 were followed.

All the ingredients (lupine flour, rice flour, whole egg, guar gum) were mixed at low speed (1) for 300 seconds in the planetary mixer (Hobart, United States), while adding egg continuously. Then water was added and mixed for 648 seconds The mixture was passed through the extruder (La Parmigiana D45, Italy). The pasta was cut to $0.20 \mathrm{~m}$ in length and allowed to dry for 14400 seconds at $60{ }^{\circ} \mathrm{C}$ in a drying chamber (Proingal SB100, Ecuador) until reaching a humidity level of $10 \%$ (Laleg et al., 2016).

\subsection{Experimental design}

A mixture-process design (I-optimal) was conducted to develop this new formulation. Rice and lupine flour amount $(\mathrm{g} / 100 \mathrm{~g})$ were selected as the mixture variables, as both must form $100 \mathrm{~g} / 100 \mathrm{~g}$ of the flour content in the formulation. The lupine flour amount varied from $10 \mathrm{~g} / 100 \mathrm{~g}$ to $30 \mathrm{~g} / 100 \mathrm{~g}$. Whole egg and guar gum were selected as "process" variables because they are factors in the experiment that are not mixture components but could affect the blending properties of the mixture ingredients (Myers et al., 2016). Guar gum varied from $0.15 \mathrm{~g} / 100 \mathrm{~g}$ to $1 \mathrm{~g} / 100 \mathrm{~g}$ and whole egg from $8 \mathrm{~g} / 100 \mathrm{~g}$ to $30 \mathrm{~g} / 100 \mathrm{~g}$. (Sarawong et al., 2014). A total of 20 trials were run that were generated using Design Expert version 10 (Table 1).

\subsection{Characterization of the pasta}

\subsubsection{Color evaluation}

To evaluate the color of the pasta, AACC method 14-22.01 (American Association of Cereal Chemists, 2010) was performed using a colorimeter (Minolta C- 410 Chroma Meter). Four measurements for each sample were taken, and light absorbance intensities were recorded in comparison with a white background on the scale of $\mathrm{L}^{\star}, \mathrm{a}^{\star}, \mathrm{b}^{\star}$. Chroma $\left(\mathrm{C}^{\star}\right)$ and hue $(\mathrm{h})$ were calculated based on these results.

\subsubsection{Amount of protein and ash}

AACCI methods 46-13.01 and 08-12.01 (2010) were used to determine protein and ash content respectively.

\subsubsection{Optimal cooking time}

In order to determine the optimal cooking time of the pasta, the AACCI method 66-50.01 (2010) was used. 25g of pasta were placed in $0.3 \mathrm{~L}$ of distilled water at boiling temperature and atmospheric pressure. The optimum time in which the pasta was cooked was defined as the time until the white core of the pasta disappears after being pressed between two transparent plates.

Table 1. Results obtained using a mixture-process design.

\begin{tabular}{|c|c|c|c|c|c|c|c|c|c|c|}
\hline \multirow[b]{2}{*}{ Run \# } & \multicolumn{3}{|c|}{ Variables } & \multirow[b]{2}{*}{$\mathrm{L}^{\mathrm{a}}$} & \multirow[b]{2}{*}{$C^{\star a}$} & \multirow[b]{2}{*}{$\mathrm{h}^{\mathrm{a}}$} & \multirow[b]{2}{*}{ Protein $^{\mathrm{b}}$} & \multirow[b]{2}{*}{$\mathrm{Ash}^{\mathrm{b}}$} & \multirow[b]{2}{*}{ Weight Gain ${ }^{\mathrm{b}}$} & \multirow[b]{2}{*}{$\begin{array}{c}\text { Cooking } \\
\text { Loss }^{\mathrm{b}}\end{array}$} \\
\hline & $\begin{array}{c}\text { Lupine }^{*} \\
\text { (g/100g) }\end{array}$ & $\frac{\text { Whole egg }}{(\mathrm{g} / 100 \mathrm{~g})}$ & $\frac{\text { Guar Gum }}{(\mathrm{g} / 100 \mathrm{~g})}$ & & & & & & & \\
\hline 1 & 20 & 8 & 0.15 & $71.93 \pm 1.28$ & $25.79 \pm 0.30$ & $1.50 \pm 0.00$ & $18.18 \pm 0.29$ & $1.30 \pm 0.05$ & $167.06 \pm 0.01$ & $12.90 \pm 0.01$ \\
\hline 2 & 20 & 30 & 1.00 & $68.75 \pm 1.16$ & $28.40 \pm 1.87$ & $1.48 \pm 0.00$ & $23.32 \pm 0.52$ & $1.26 \pm 0.05$ & $168.11 \pm 0.01$ & $8.03 \pm 0.01$ \\
\hline 3 & 20 & 30 & 1.00 & $69.94 \pm 1.37$ & $27.15 \pm 0.57$ & $1.49 \pm 0.01$ & $19.92 \pm 0.29$ & $1.15+0.05$ & $184.18 \pm 0.01$ & $8.68 \pm 0.01$ \\
\hline 4 & 30 & 30 & 0.15 & $70.23 \pm 0.68$ & $28.62 \pm 0.29$ & $1.48 \pm 0.00$ & $22.58 \pm 0.52$ & $1.30 \pm 0.05$ & $175.70 \pm 0.01$ & $9.92 \pm 0.01$ \\
\hline 5 & 10 & 8 & 1.00 & $70.10 \pm 0.24$ & $22.80 \pm 0.64$ & $1.50 \pm 0.00$ & $14.28 \pm 0.29$ & $0.94 \pm 0.02$ & $285.47 \pm 0.01$ & $19.68 \pm 0.01$ \\
\hline 6 & 30 & 8 & 0.11 & $68.38 \pm 0.82$ & $27.39 \pm 0.16$ & $1.48 \pm 0.00$ & $21.93 \pm 0.52$ & $1.37 \pm 0.05$ & $171.73 \pm 0.01$ & $15.76 \pm 0.01$ \\
\hline 7 & 10 & 30 & 0.15 & $71.37 \pm 0.52$ & $28.09 \pm 0.45$ & $1.47 \pm 0.00$ & $16.07 \pm 0.52$ & $1.00 \pm 0.05$ & $200.34 \pm 0.01$ & $8.73 \pm 0.01$ \\
\hline 8 & 20 & 30 & 0.15 & $69.57 \pm 0.47$ & $29.21 \pm 0.23$ & $1.47 \pm 0.00$ & $19.75 \pm 0.52$ & $1.19 \pm 0.05$ & $176.23 \pm 0.01$ & $10.00 \pm 0.01$ \\
\hline 9 & 20 & 8 & 1.00 & $71.51 \pm 0.18$ & $26.05 \pm 0.93$ & $1.50 \pm 0.00$ & $18.12 \pm 0.29$ & $1.36 \pm 0.05$ & $170.51 \pm 0.01$ & $10.56 \pm 0.01$ \\
\hline 10 & 20 & 30 & 1.00 & $70.01 \pm 1.90$ & $28.50 \pm 0.43$ & $1.47 \pm 0.00$ & $18.83 \pm 0.52$ & $1.43 \pm 0.03$ & $158.34 \pm 0.01$ & $7.89 \pm 0.01$ \\
\hline 11 & 30 & 8 & 1.00 & $69.39 \pm 0.41$ & $26.92 \pm 0.16$ & $1.48 \pm 0.00$ & $22.02 \pm 0.52$ & $1.50 \pm 0.03$ & $165.74 \pm 0.01$ & $10.55 \pm 0.01$ \\
\hline 12 & 20 & 8 & 1.00 & $72.50 \pm 1.69$ & $25.53 \pm 0.43$ & $1.51 \pm 0.00$ & $17.37 \pm 0.29$ & $1.18 \pm 0.05$ & $172.70 \pm 0.01$ & $10.65 \pm 0.01$ \\
\hline 13 & 10 & 19 & 0.36 & $74.53 \pm 1.20$ & $23.90 \pm 0.18$ & $1.51 \pm 0.00$ & $14.74 \pm 0.29$ & $0.94 \pm 0.02$ & $220.15 \pm 0.01$ & $9.29 \pm 0.01$ \\
\hline 14 & 20 & 30 & 0.15 & $69.01 \pm 0.31$ & $29.03 \pm 0.43$ & $1.47 \pm 0.00$ & $19.69 \pm 0.29$ & $1.30 \pm 0.05$ & $187.51 \pm 0.01$ & $8.04 \pm 0.01$ \\
\hline 15 & 25 & 19 & 0.57 & $53.34 \pm 1.08$ & $27.90 \pm 0.19$ & $1.48 \pm 0.00$ & $20.73 \pm 0.52$ & $1.55 \pm 0.03$ & $178.09 \pm 0.01$ & $7.92 \pm 0.01$ \\
\hline 16 & 25 & 19 & 0.57 & $68.85 \pm 0.95$ & $27.51 \pm 1.05$ & $1.49 \pm 0.00$ & $20.80 \pm 0.52$ & $1.62 \pm 0.03$ & $180.93 \pm 0.01$ & $9.83 \pm 0.01$ \\
\hline 17 & 20 & 8 & 0.15 & $72.03 \pm 0.58$ & $24.47 \pm 0.57$ & $1.52 \pm 0.00$ & $17.94 \pm 0.29$ & $1.31 \pm 0.05$ & $187.48 \pm 0.01$ & $14.27 \pm 0.01$ \\
\hline 18 & 30 & 30 & 1.00 & $69.20 \pm 0.92$ & $21.69 \pm 0.15$ & $1.47 \pm 0.00$ & $21.92 \pm 0.52$ & $1.55 \pm 0.03$ & $161.23 \pm 0.01$ & $8.26 \pm 0.01$ \\
\hline 19 & 10 & 30 & 1.00 & $73.19 \pm 0.44$ & $24.74 \pm 0.70$ & $1.51 \pm 0.00$ & $15.84 \pm 0.29$ & $0.65 \pm 0.02$ & $214.20 \pm 0.01$ & $7.41 \pm 0.01$ \\
\hline 20 & 10 & 8 & 0.15 & $75.81 \pm 0.27$ & $21.54 \pm 0.29$ & $1.52 \pm 0.00$ & $13.63 \pm 0.29$ & $0.95 \pm 0.02$ & $198.47 \pm 0.01$ & $18.67 \pm 0.01$ \\
\hline
\end{tabular}

${ }^{\star}$ Partial substitution percentage over $100 \mathrm{~g} / 100 \mathrm{~g}$ rice; ${ }^{\mathrm{a}}$ Mean among four measurements; ${ }^{\mathrm{b}}$ Mean among two measurements. 


\subsubsection{Weight gain}

To measure weight increase, the AACC method 66-50.01 (American Association of Cereal Chemists, 2010) was used with some modifications. Samples were cooked to their optimal point and were drained for 28.80 seconds. Difference between the weight of the pasta before and after cooking was obtained.

\subsubsection{Cooking Loss}

Cooking loss was determined by the AACC method 66-50.01 (American Association of Cereal Chemists, 2010) with some modifications. The changes in pasta were analyzed quantitatively. Loss was evaluated after cooking $10 \mathrm{~g}$ of pasta in $0.1 \mathrm{~L}$ of distilled water at boiling temperature during the optimum time. The resulting solution, after removing the cooked pasta from the water, was evaporated in a hot air oven at $105^{\circ} \mathrm{C}$. The residues, measured in grams, were taken as the weight of the original pasta that was lost during the cooking period.

\subsection{Desirability function}

In order to evaluate the results of the seven response variables simultaneously, a desirability function was used. The desired objectives were considered, to either maximize or minimize each of the response variables. This statistical analysis has two main parts, the individual and the composite desirability. The individual desirability $\left(d_{i}\right)$ determines how the structure optimizes an individual response (Montgomery, 2012).

\subsection{Consumer testing}

A consumer test was performed to measure acceptance attributes that might affect product consumption (Lawless \& Heymann, 2010). An affective test was developed using a 4-question survey (overall, appearance, flavor and texture preferences) where a 9-point hedonic scale was used for each question (Lim, 2011). 112 consumers (50 women, 62 men) evaluated $20 \mathrm{~g}$ of three samples that were identified with random numbers (Hough et al., 2006). Two of these samples were those with the highest values in the desirability function (first sample: $30 \%$ lupine flour, $70 \%$ rice flour, $30 \%$ whole egg, $0.15 \%$ guar gum; second sample: $20 \%$ lupine flour, $80 \%$ rice flour, $30 \%$ whole egg, $0.15 \%$ guar gum) while the third sample, unlike the other two, was chosen with the aim of minimizing the taste of the lupine (third sample: $10 \%$ lupine flour, $90 \%$ rice flour, 30\% whole egg, $0.15 \%$ guar gum). Serving order was sequential monadic, based on a mutually orthogonal latin square design, in order to minimize context effects (Demirkale et al., 2016). The test was performed in a controlled environment in the sensory laboratory at Universidad San Francisco de Quito. Statistical analysis was performed using Minitab 16.

A completely randomized block design was carried out to analyze the results of the consumer test. The following is the resulting model:

$y_{i j}=\mu+\tau_{i}+\beta_{j}+\varepsilon_{i j}\{i=1,2,3 . j=1,2, \ldots, 112$

Where:

$y_{i j}=$ response variable

$\mu=$ average $\tau_{i}=$ effect of the $\mathrm{i}$-th treatment

$\beta_{j}=$ effect of the i-th block

$\varepsilon_{i j}=$ error

\subsection{Proximal analysis of samples}

Based on the consumer testing results, the best sample was selected, and a proximal analysis was performed on this sample and compared with a control $(100 \mathrm{~g} / 100 \mathrm{~g}$ rice $)$.

\subsection{Statistical analysis}

Statistical analysis for the seven response variables was performed using Design Expert 10 with $\alpha=0.05$. The complete model, assuming that all its terms are significant, is presented in Equation 1 (Myers et al., 2016).

$y=\beta_{1} x_{1}+\beta_{2} x_{2}+\beta_{12} x_{1} x_{2}+\alpha_{1} x_{1} x_{2}+\alpha_{2} x_{2} z_{2}+\alpha_{3} x_{1} x_{2} z_{1}+\alpha_{1} x_{1} z_{2}+$

$\alpha_{2} x_{2} z_{1}+\alpha_{3} x_{1} x_{2}+\delta_{1} x_{1} z_{1} z_{2}+\delta_{2} x_{2} z_{1} z_{2}+\delta_{3} x_{1} x_{2} z_{1} z_{2}+\varepsilon$

Where:

$\mathrm{y}=$ response variable

$x_{i}=$ mixture variables

$z_{i}=$ process variables

$\beta_{i}=$ linear and non-linear properties of the components of each mixture

$\alpha i=$ main effects and interactions of the process variables

$\delta \mathrm{i}=$ mixture components and process variables

$\varepsilon_{i j}=$ error

\section{Results and discussion}

\subsection{Color evaluation}

One of the most important factors consumers consider when buying pasta is the color of the product (Giuberti et al., 2015). Luminosity results vary from 53.34 to 75.81 (Table 1 ). A high variation in the measurements can be attributed to the lupine flour's original color. This data also indicates the Munsell value, which represents the lightness or darkness of the samples (Nielsen, 2009). The resulting model presented a hierarchical model with linear, quadratic and cubic terms for the mixture variables. The process variables were not significant $(p<0.05)$. The most significant factor was the cubic term with a negative coefficient of -105.98 , followed by the rice and lupine flours with very close coefficients of 73.00 and 69.54, respectively (Table 2). Gluten-free pasta that has gone through the cooking process is expected to have a decreased level of luminosity (Flores-Silva et al., 2014).

For the chroma value $\left(C^{*}\right)$, results varied from 21.54 to 29.20 , which present a lower variation than the results found for luminosity. The resulting model presented quadratic terms for the mixture variables and two-factor interaction terms for the process variables. The most influential term was rice flour content with a positive coefficient of 24.11 (Table 2). 
Table 2. Mathematical models for each response variable.

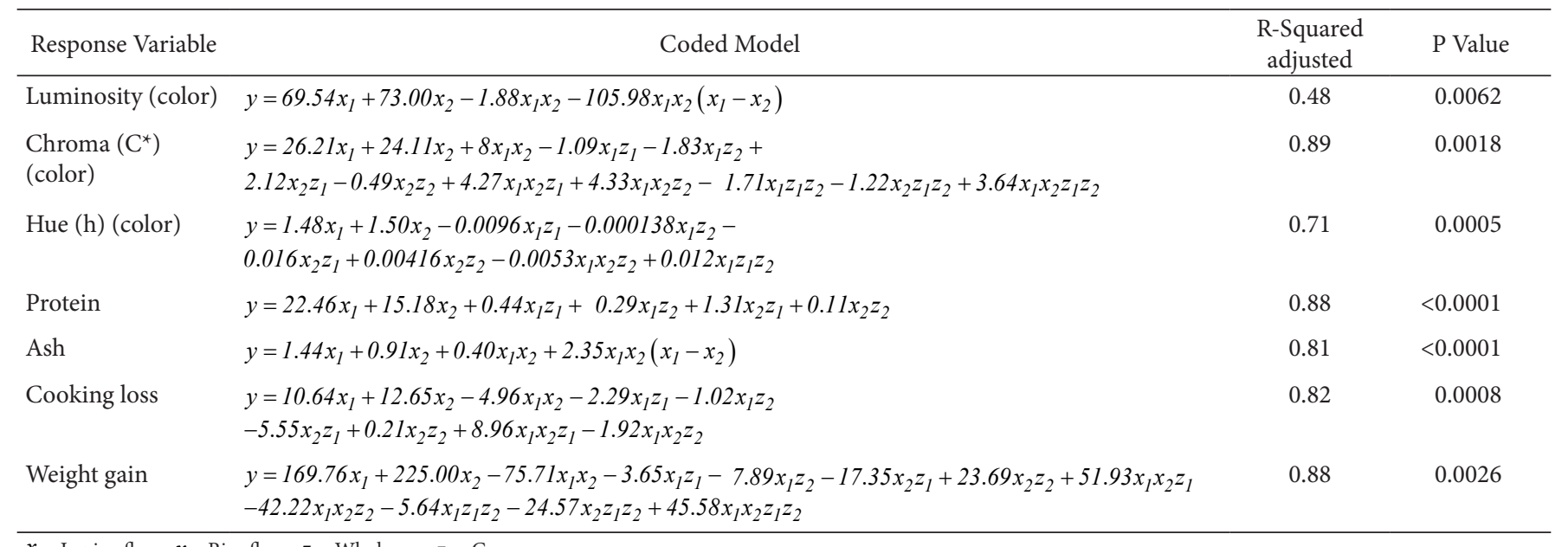

$x_{1}=$ Lupine flour; $x_{2}=$ Rice flour; $z_{1}=$ Whole egg; $z_{2}=$ Guar gum.

A similar behavior was reported in the results for hue (h). This variable adjusts to a model with linear terms for the mixture variables and two-factor interaction terms for the process variables. $(\mathrm{p}<0.05)$. The range of the results varies from $1.47^{\circ}$ to $1.52^{\circ}$, much closer to each other in comparison to the results for luminosity and chroma. Both lupine and rice flour were the most important factors in the model.

\subsection{Protein and ash content}

The protein and ash content of the gluten-free pasta are presented in Table 1. Protein content of the samples were explained by a model with linear terms for both the mixture and process variables $(\mathrm{p}<0.05)$. On the other hand, ash content adjusts to a hierarchical model with linear, quadratic and cubic terms for the mixture variables but non-significant terms for the process variables.

Protein results vary from $13.64 \mathrm{~g} / 100 \mathrm{~g}$ to $23.31 \mathrm{~g} / 100 \mathrm{~g}$ and, based on the statistical analysis, lupine flour is the most important factor in the mathematical model. Lupine flour used in this study is characterized by a high protein content (32.00-52.60 g/100g dw) (Carvajal-Larenas et al., 2014). Therefore, the addition of lupine flour in gluten-free products improves the protein content and the nutritional value of the product. It is important to note that lupine has a high level of lysine (Lys), one of the 10 essential amino-acids for the human body (Guyton, 2006). The protein efficiency ratio (PER) of the lupine has been reported between 0.83 and 1.00 (Carvajal-Larenas et al., 2016). As shown in Figure 1D, the response surface indicates that the higher the level of lupine and egg, the higher the protein content. These results confirm findings from previous studies. Whole lupine and its derivatives, such as flour, have been used to improve the nutritional properties of food products (Güémes-Vera et al., 2008).

Several authors reported that lupine can improve the biological quality of proteins when combined with other cereals (corn, rice, etc.). (Martínez et al., 2003).
The most significant term in the mathematical model for the increase in ash content is the cubic term that involves both lupine and rice flours. Lupine contains approximately $3.30 \mathrm{~g} / 100 \mathrm{~g}$ of minerals in its composition (Jacobsen \& Mujica, 2006), while rice is a source of proteins and minerals that are distributed equally for its iron, phosphorus, calcium manganese, selenium and zinc (Pastorelli et al., 2018).

\subsection{Quality of gluten-free pasta (weight gain and cooking loss)}

After evaluating the ideal cooking time of the 20 samples, a time of 450 seconds was standardized to measure weight gain and loss of solids for all runs. Values found were between $158.35 \mathrm{~g} / 100 \mathrm{~g}$ to $285.47 \mathrm{~g} / 100 \mathrm{~g}$ and $7.41 \mathrm{~g} / 100 \mathrm{~g}$ to $19.68 \mathrm{~g} / 100 \mathrm{~g}$, respectively.

The mathematical model obtained for weight gain is a quadratic model for the mixture variables and an interaction model for the process variables. The factors that most affect the model are the lupine and rice flour, which can be explained by the fact that lupine has a high-water absorption rate and because lupine flour can increase up to three times the water absorption value. Certain stages of processing, such as soaking, elimination of alkaloids (process of de-bittering of the grain) and cooking, improve the capacity of water absorption due to the elimination of components such as lipids and polyphenols (Carvajal-Larenas et al., 2014). At the same time, starch obtained from lupine $(2.99 \mathrm{~g} / 100 \mathrm{~g})$ and from rice is gelatinized. The molecular order is destroyed, breaking hydrogen bridges gradually and irreversibly, and the granules lose their crystallinity by absorbing a large quantity of water (Hernández- Medina et al., 2008). In the same way, rice has a low lipid content, $2.2 \mathrm{~g} / 100 \mathrm{~g}$ (Kitta et al., 2005), allowing a high-water absorption capacity. This is confirmed by the response surface (Figure $1 \mathrm{~F}$ ) where, with a greater substitution of lupine in the formulation, this response increases.

On the other hand, the loss of solids is explained by the mathematical model with quadratic terms for the mixture variables and linear terms for process variables (Table 2). The factors with 


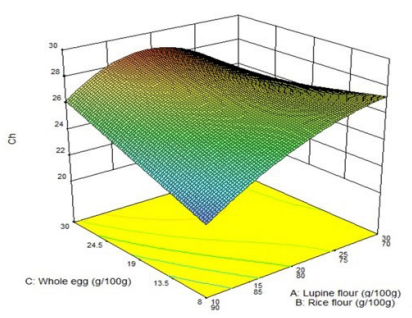

(A)

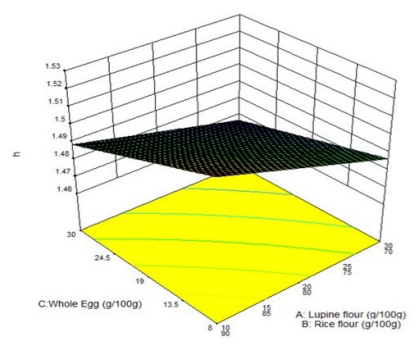

(C)

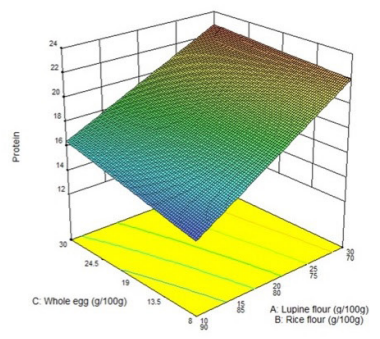

(E)

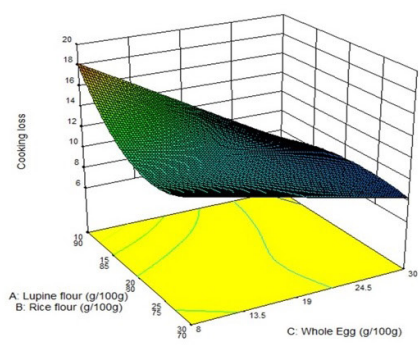

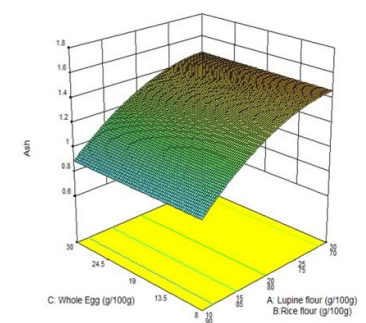

(B)

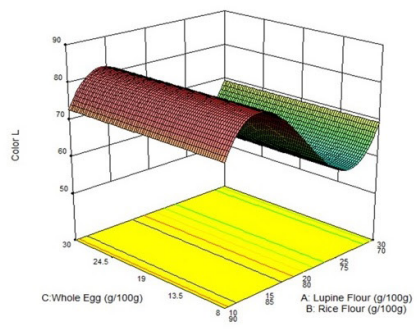

(D)

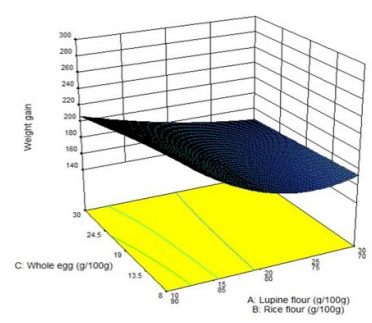

(F)

(G)

Figure 1. Response Surface; Chroma (A), ash (B), h (C), luminosity (D), protein (E), Weight gain (F), Cooking loss (G).

the highest influence were lupine and rice. The loss of solids is an important factor to measure the quality of cooked pasta. To obtain a good quality pasta, it is important to have less than a $12 \mathrm{~g} / 100 \mathrm{~g}$ loss of solids when made with wheat (Delcour \& Hoseney, 2010). However, for gluten-free pasta, because of the lack of gluten, starch polymers are less efficiently entrapped in the matrix, resulting in a product with high cooking loss and low firmness (Marti et al., 2014). In this study, an average of $10.85 \mathrm{~g} / 100 \mathrm{~g}$ was obtained, which shows that this pasta is within the recommended standards.

\subsection{Desirability function}

For the desirability analysis, each response variable received a weight on a discrete scale ( 5 highest, 1 lowest) based on their importance of pasta: luminosity $=1 ; \mathrm{C}=3 ; \mathrm{h}=3$; protein content $=5$; ash content $=5$; weight gain $=5$; loss of solids $=5$.

The desirability algorithm gave 37 possible ideal answers, with the highest $\mathrm{D}$-value of 0.58 . The formulation with the highest desirability function consisted of $30 \mathrm{~g} / 100 \mathrm{~g}$ lupine flour, $70 \mathrm{~g} / 100 \mathrm{~g}$ flour rice, $30 \mathrm{~g} / 100 \mathrm{~g}$ egg and $0.15 \mathrm{~g} / 100 \mathrm{~g}$ 
Table 3. Proximal analysis of control and optimal pasta

\begin{tabular}{lcc}
\hline \multicolumn{1}{c}{ Component } & $\mathrm{CP}$ & $\mathrm{Ch} 20$ \\
\hline Ash $(\mathrm{g} / 100 \mathrm{~g})$ & $0.8 \pm 0.001^{a}$ & $1.1 \pm 0.007^{b}$ \\
Protein content $(\mathrm{g} / 100 \mathrm{~g})$ & $11.4 \pm 0.042^{a}$ & $18.6 \pm 0.014^{b}$ \\
Unsaturated Fat $(\mathrm{g} / 100 \mathrm{~g})$ & $3.3 \pm 0.049^{a}$ & $7 \pm 0.127^{b}$ \\
Fiber Content $(\mathrm{g} / 100 \mathrm{~g})$ & $0.3 \pm 0.001^{a}$ & $0.68 \pm 0.001^{b}$ \\
Humidity & $5.5 \pm 0.049^{a}$ & $9.8 \pm 0.057^{b}$ \\
Carbohydrates & $78.7 \pm 0.057^{a}$ & $62.7 \pm 0.092^{b}$ \\
\hline
\end{tabular}

$\mathrm{CP}=$ Gluten-free control pasta $(100 \mathrm{~g} / 100 \mathrm{~g}$ rice $) ; \mathrm{Ch} 20(\mathrm{D}=0.536)=20 \mathrm{~g} / 100 \mathrm{~g}$ lupine flour, $30 \mathrm{~g} / 100 \mathrm{~g}$ egg, $0.15 \mathrm{~g} / 100 \mathrm{~g}$ guar gum; Means with different letters in the same row indicate statistical difference between samples $(\mathrm{p}<0.05)$.

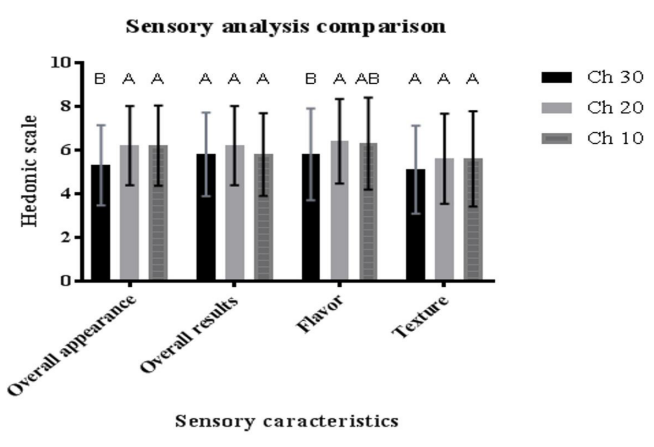

Figure 2. Consumer testing results (Means with different letters indicate statistical difference between samples $(\mathrm{p}<0.05))$.

Table 4. Predicted and Experimental values obtained in the models validation.

\begin{tabular}{|c|c|c|c|c|c|c|c|c|c|}
\hline \multirow[b]{2}{*}{ Parameter } & \multicolumn{3}{|c|}{ Lupinus 30\% } & \multicolumn{3}{|c|}{ Lupinus $20 \%$} & \multicolumn{3}{|c|}{ Lupinus $10 \%$} \\
\hline & $\begin{array}{l}\text { Predicted } \\
\text { value }\end{array}$ & $\begin{array}{l}\text { Experimental } \\
\text { value }\end{array}$ & $\begin{array}{c}\text { Relative } \\
\text { deviation } \\
(\%)\end{array}$ & $\begin{array}{l}\text { Predicted } \\
\text { value }\end{array}$ & $\begin{array}{l}\text { Experimental } \\
\text { value }\end{array}$ & $\begin{array}{c}\text { Relative } \\
\text { deviation } \\
(\%)\end{array}$ & $\begin{array}{l}\text { Predicted } \\
\text { value }\end{array}$ & $\begin{array}{l}\text { Experimental } \\
\text { value }\end{array}$ & $\begin{array}{c}\text { Relative } \\
\text { deviation } \\
(\%)\end{array}$ \\
\hline Luminosity ${ }^{*}$ & 80.47 & $70.23 \pm 0.68$ & 12,73 & 82.18 & $71.93 \pm 1.28$ & 12.47 & 80.11 & $71.37 \pm 0.52$ & 10.90 \\
\hline Chroma $^{*}$ & 26.46 & $28.62 \pm 0.29$ & 0.56 & 27.10 & $25.79 \pm 0.30$ & 4.83 & 26.67 & $28.09 \pm 0.45$ & 5.32 \\
\hline Hue $^{\star}$ & 1.50 & $1.48 \pm 0.00$ & 1.33 & 1.50 & $1.50 \pm 0.00$ & 0.00 & 1.50 & $1.47 \pm 0.00$ & 2.00 \\
\hline Protein ${ }^{\star *}$ & 17.68 & $22.58 \pm 0.52$ & 21.7 & 16.73 & $18.18 \pm 0.29$ & 8.66 & 16.27 & $16.07 \pm 0.52$ & 1.22 \\
\hline Weight Gain ${ }^{\star *}$ & 191.83 & $175.70 \pm 0.01$ & 8.40 & 201.34 & $167.06 \pm 0.01$ & 17.02 & 209.28 & $200.34 \pm 0.01$ & 4.31 \\
\hline Weight Loss** & 10.10 & $9.92 \pm 0.01$ & 1.78 & 11.16 & $12.90 \pm 0.01$ & 15.59 & 10.64 & $8.73 \pm 0.01$ & 17.95 \\
\hline
\end{tabular}

${ }^{\star}$ Arithmetic means of four replicates; ${ }^{* *}$ Arithmetic means of two replicates.

guar gum formulation. The second best product consisted of $19.93 \mathrm{~g} / 100 \mathrm{~g}$ lupine flour, $80.06 \mathrm{~g} / 100 \mathrm{~g}$ rice flour, $30 \mathrm{~g} / 100 \mathrm{~g}$ egg and $0.15 \mathrm{~g} / 100 \mathrm{~g}$ guar gum in its formulation $(\mathrm{D}=0.53)$.

\subsection{Consumer tests}

Results showed that appearance and flavor preferences were statistically different among the three samples, while overall liking and texture liking were not statistically different (Figure 2). These results could be explained because drying the lupine grain before grinding improves its organoleptic characteristics. This is because it causes the flour to have a neutral taste or tends to a light bitter taste (Carvajal-Larenas et al., 2014). Overall results showed that the sample with the highest level of acceptability was the one with $20 \mathrm{~g} / 100 \mathrm{~g}$ lupine flour, $30 \mathrm{~g} / 100 \mathrm{~g}$ egg, $0.15 \mathrm{~g} / 100 \mathrm{~g}$ guar gum (Ch20).

\subsection{Proximal analysis of samples}

The results of the proximal analysis are presented in Table 3.

Pasta with lupine flour (Ch20) had better nutritional characteristics than the control pasta. The protein level of pasta with lupine flour increased by $38 \mathrm{~g} / 100 \mathrm{~g}$ due to its high protein content: $33.9-43.3 \mathrm{~g} / 100 \mathrm{~g}$ dw. Also, mineral content increased by $27 \mathrm{~g} / 100 \mathrm{~g}$ due to its high calcium and phosphorus content: $320 \mathrm{mg} / 100 \mathrm{~g} \mathrm{dw}$ and $753 \mathrm{mg} / 100 \mathrm{~g} \mathrm{dw}$, respectively (Carvajal-Larenas et al., 2014). Also, lupine contains a high level of fiber ( $8.2 \mathrm{~g} / 100 \mathrm{~g})$ (Carvajal-Larenas et al., 2016). For this reason, pasta with lupine flour increased its fiber content by
$56 \mathrm{~g} / 100 \mathrm{~g}$. Finally, lupine has approximately $80 \mathrm{~g} / 100 \mathrm{~g}$ of unsaturated fatty acids (Carvajal-Larenas et al., 2014), which causes a $53 \mathrm{~g} / 100 \mathrm{~g}$ increase of lipids in the pasta.

Moreover, the experimental value of each response was compared with those predicted by the equations of the model to obtained the relative deviation (Table 4). When comparing the experimental values with those predicted by the obtained equations it was observed low values for the relative deviation $(<20 \%)$, validating the mathematical models obtained in this study.

\section{Conclusions}

This study showed that Lupinus Mutabilis flour is a useful ingredient for the nutritional improvement of gluten-free products. Due to its higher nutritional quality, substituting lupine flour in rice pasta increases ash content $(37.5 \mathrm{~g} / 100 \mathrm{~g})$, protein content $(63.15 \mathrm{~g} / 100 \mathrm{~g})$, unsaturated fats $(112.12 \mathrm{~g} / 100 \mathrm{~g})$ and fiber content $(126.66 \mathrm{~g} / 100 \mathrm{~g})$, which increase pasta quality. In regards to pasta, lupine flour is the variable that most affects the weight gain due to its water absorption capacity. Pasta sensory characteristics such as color were influenced by the addition of lupine flour. This study also provides a scientific approach to general consumer acceptance, where the preferred level of lupine in gluten-free pasta is $20 \mathrm{~g} / 100 \mathrm{~g}$, with a formulation of $30 \mathrm{~g} / 100 \mathrm{~g}$ egg and $0.15 \mathrm{~g} / 100 \mathrm{~g}$ guar gum. 


\section{Acknowledgements}

This project has been possible thanks to the Universidad San Francisco de Quito- USFQ- College of Engineering research grant.

\section{References}

American Association of Cereal Chemists. (2010). Approved methods of the AACCI (10th ed.). Minnesota: AACC International.

Carvajal-Larenas, F. E., Linnemann, A., Nout, M., Koziol, M., \& Van Boekel, M. (2016). Lupinus mutabilis: composition, uses, toxicology and debittering. Critical Reviews in Food Science and Nutrition, 56(9), 1454-1487. http://dx.doi.org/10.1080/10408398.2013.7720 89. PMid:26054557.

Carvajal-Larenas, F. E., Van Boekel, M. J. A. S., Koziol, M., Nout, M. J. R., \& Linnemann, A. R. (2014). Effect of processing on the diffusion of alkaloids and quality of lupinus mutabilis sweet. Journal of Food Processing and Preservation, 38(4), 1461-1471. http://dx.doi. org/10.1111/jfpp.12105.

Delcour, J., \& Hoseney, R. (2010). Principles of cereal science and technology (pp. 229-239). Saint Paul: AACC International, Inc. http://dx.doi.org/10.1094/9781891127632.014.

Demirkale, F., Donovan, D., Hall, J., Khodkar, A., \& Rao, A. (2016). Difference covering arrays and pseudo-orthogonal latin squares. Graphs and Combinatorics, 32(4), 1353-1374. http://dx.doi.org/10.1007/ s00373-015-1649-8.

Flores-Silva, P., Berrios, J., Pan, J., Agama-Acevedo, E., MonsalveGonzález, A., \& Bello-Pérez, L. (2014). Gluten-free spaghetti with unripe plantain, chickpea and maize: Physicochemical, texture and sensory properties. CYTA: Journal of Food, 13(2), 159-166. http:// dx.doi.org/10.1080/19476337.2014.929178.

Giuberti, G., Gallo, A., Cerioli, C., Fortunati, P., \& Masoero, F. (2015). Cooking quality and starch digestibility of gluten free pasta using new bean flour. Food Chemistry, 175, 43-49. http://dx.doi.org/10.1016/j. foodchem.2014.11.127. PMid:25577049.

Granito, M., Torres, A., \& Guerra, M. (2003). Desarrollo y evaluación de una pasta a base de trigo, maíz, yuca y frijol. Interciencia, 28, 372-379.

Güémes-Vera, N., Peña-Bautista, R., Jiménez-Martínez, C., Dávila-Ortiz, G., \& Calderón-Domínguez, G. (2008). Effective detoxification and decoloration of Lupinus mutabilis seed derivatives, and effect of these derivatives on bread quality and acceptance. Journal of the Science of Food and Agriculture, 88(7), 1135-1143. http://dx.doi. org/10.1002/jsfa.3152.

Guyton, A. C. (2006). Tratado de fisiología médica. Spain: Elsevier.

Hernández-Medina, M., Torruco-Uco, J. G., Chel-Guerrero, L., \& Betancur-Ancona, D. (2008). Caracterización fisicoquímica de almidones de tubérculos cultivados en Yucatán, México. Food Science and Technology, 28(3), 718-726. http://dx.doi.org/10.1590/ S0101-20612008000300031.

Hough, G., Wakeling, I., Mucci, A., Chambers, E. 4th, Gallardo, I., \& Alves, L. (2006). Number of consumers necessary for sensory acceptability tests. Food Quality and Preference, 17(6), 522-526. http://dx.doi.org/10.1016/j.foodqual.2005.07.002.

Jacobsen, S. \& Mujica, A. (2006). El tarwi (lupinus mutabilis Sweet.) y sus parientes silvestres. Botánica Económica de los Andes Centrales, 28(1), 458-482.
Karlin, S., Karlin, E., Meiller, T., \& Bashirelahi, N. (2016). Dental and oral considerations in pediatric celiac disease. Journal of Dentistry for Children, 83(2), 67-70. PMid:27620516.

Kitta, K., Ebihara, M., Iizuka, T., Yoshikawa, R., Isshiki, K., \& Kawamoto, S. (2005). Variations in lipid content and fatty acid composition of major non-glutinous rice cultivars in Japan. Journal of Food Composition and Analysis, 18(4), 269-278. http://dx.doi.org/10.1016/j. jfca.2004.10.001.

Laleg, K., Cassan, D., Barron, C., Prabhasankar, P., \& Micard, V. (2016). Structural, Culinary, Nutritional and Anti-Nutritional Properties of High Protein, Gluten Free, 100\% Legume Pasta. PLoS One, 11(9), e0160721. http://dx.doi.org/10.1371/journal.pone.0160721. PMid:27603917.

Lawless, H., \& Heymann, H. (2010). Sensory evaluation of food: principles and practices (pp. 303-323). New York: Springer. http:// dx.doi.org/10.1007/978-1-4419-6488-5_13.

Lim, J. (2011). Hedonic scaling: a review of methods and theory. Food Quality and Preference, 22, 733-747. http://dx.doi.org/10.1016/j. foodqual.2011.05.008.

Malalgoda, M., \& Simsek, S. (2016). Celiac disease and cereal proteins. Food Hydrocolloids, 68, 108-113. http://dx.doi.org/10.1016/j. foodhyd.2016.09.024.

Marti, A., Barbiroli, A., Marengo, M., Fongaro, L., Iametti, S., \& Pagani, M. (2014). Structuring and texturing gluten-free pasta: egg albumen or whey proteins. European Food Research and Technology, 238(2), 217-224. http://dx.doi.org/10.1007/s00217-013-2097-4.

Martínez, C. J., Loarca-Piña, G., \& Ortíz, G. D. (2003). Antimutagenic activity of phenolic compounds, oligosaccharides and quinolizidinic alkaloids from Lupinus campestris seeds. Food Additives and Contaminants, 20(10), 940-948. http://dx.doi.org/10.1080/026520 30310001605998. PMid:14594678.

Montgomery, D. C. (2012). Design and analysis of experiments. New Jersey, USA. Wiley.

Myers, R., Montgomery, D., \& Anderson-Cook, C. (2016). Response surface methodology. New Jersey: Wiley.

Nielsen, S. (2009). Análisis de los alimentos. Zaragoza: Acribia.

Pastorelli, A., Angeletti, R., Binato, G., Mariani, M., Cibin, V., Morelli, A., Ciardullo, S., \& Stacchini, P. (2018). Exposure to cadmium through Italian rice (Oryza sativa L.): consumption and implications for human health. Journal of Food Composition and Analysis, 69(11), 115-121. http://dx.doi.org/10.1016/j.jfca.2018.02.005.

Polowick, P. L., Loukanina, N. N., \& Doshi, K. M. (2014). Agrobacteriummediated transformation of tarwi (Lupinus mutabilis Sweet), a potential platform for the production of plant-made proteins. In Vitro Cellular \& Developmental Biology. Plant, 50(4), 401-411. http:// dx.doi.org/10.1007/s11627-014-9601-9.

Rubio-Tapia, A., Ludvigsson, J., Brantner, T., Murray, J., \& Everhart, J. (2012). The prevalence of celiac disease in the United States. The American Journal of Gastroenterology, 107(10), 1538-1545. http:// dx.doi.org/10.1038/ajg.2012.219. PMid:22850429.

Sarawong, C., Rodríguez Gutiérrez, Z. C., Berghofer, E., \& Schoenlechner, R. (2014). Gluten-free pasta: effect of green plantain flour addition and influence of starch modification on the functional properties and resistant starch content. International Journal of Food Science \& Technology, 49(12), 2650-2658. http://dx.doi.org/10.1111/ijfs.12599. 